\title{
MENUMBUHKAN RASA KEPEDULIAN SISWA TERHADAP KEBERSIHAN LINGKUNGAN DI SEKOLAH MA AL MASYHUR BUGUL KIDUL KOTA PASURUAN
}

\author{
Yuniar Mujiwati ${ }^{1}$, Maya Paramitha ${ }^{2}$, M. Zainul Arifin Sungsang Maulana ${ }^{3}$ \\ 1) Prodi PPKn' Fakultas Pedagogi dan Psikologi, Universitas PGRI Wiranegara Pasuruan \\ ${ }^{2)}$ Prodi Pendidikan Bahasa Inggris, Fakultas Pedagogi dan Psikologi, Universitas PGRI Wiranegara Pasuruan \\ ${ }^{3}$ Prodi Pendidikan Bahasa Indonesia, Fakultas Pedagogi dan Psikologi, Universitas PGRI Wiranegara \\ Pasuruan \\ e-mail: yuniar.caliptra@gmail.com
}

\begin{abstract}
Abstrak
Permasalahan yang di angkat di dalam jurnal ini yakni mengenai bagaimana cara untuk menumbuhkan rasa kepedulian siswa terhadap kebersihan lingkungan di sekolah MA AL MASYHUR Bugul Kidul Kota Pasuruan. Setelah kami mengadakan survei kami menemukan permasalah utama yakni kurangnya kesadaran akan pentingnya menjaga kebersihan lingkungan dan kurangnya failitas tempat pembuangan sampah. Seperti yang telah kita ketahui bahwa kebersihan lingkungan sekolah memiliki peran penting bagi siswa maupun dewan guru di sekolah tersebut. Dengan terciptanya lingkungan sekolah yang bersih dan sehat dapat memberikan dampak positif bagi kegiatan belajar mengajar. Untuk menciptakan lingkungan sekolah yang bersih tentu di perlukan kerja sama antara guru dengan murid di sekolah tersebut, ketika guru atau sekolah berupaya bersosialisasi dan menciptakan lingkungan yang bersih maka tugas selanjutnya yang di lakukan oleh siswa yakni menjaga kebersihan lingkungan dengan cara senantiasa membuang sampah pada tempatnya. Dari tindakan kecil ini lah siswa dapat menumbuhkan rasa kepedulian nya untuk menjaga lingkungan sekolah yang bersih dan siswa menjadi terbiasa dalam menjaga kebersihan lingkungan sekolah.
\end{abstract}

Kata Kunci: Kebersihan, Kepedulian, Lingkungan, Sosialisasi

\section{Abstract}

The problem raised in this journal is about how to grow students' sense of environmental cleanliness in the MA AL MASYHUR school in the kidul city of Pasuruan. After we conducted the survey we found that the main problems were lack of awareness of the importance of maintaining environmental cleanliness and lack of landfill facilities. As we already know that the cleanliness of the school environment has an important role for students and the board of teachers at the school. The creation of a clean and healthy school environment can have a positive impact on teaching and learning activities. To create a clean school environment, of course cooperation is needed between the teacher and students at the school, when the teacher or school seeks to socialize and create a clean environment, the next task undertaken by students is to maintain environmental cleanliness by always throwing trash in its place. It is from this small action that students can foster a sense of caring to maintain a clean school environment and students become accustomed to maintaining a clean school environment

Keywords: Clenliness, Careness, Environment, Sosialization

\section{PENDAHULUAN}

Kebersihan merupakan masalah penting namun sangat sulit diatasi. Kebersihan mungkin masalah kecil yang sepele, tapi nyatanya malah disepelekan oleh kebanyakan orang, seperti yang telah kita ketahui terdapat banyak orang tidak sadar akan pentingnya menjaga lingkungan termasuk menjaga kebersihan lingkungan sekolah. Kebersihan lingkungan sekolah sangatlah berpengaruh 
bagi aktifitas belajar mengajar, ketika kondisi kebersihan lingkungan di sekolah tersebut tidak baik maka dapat menimbulkan ketidaknyamanan dan menganggu aktifitas belajar mengajar begitupun sebaliknya dan sekolah dianggap sebagai tepat yang tepat dan efektif untuk menumbuhkan rasa kepedulian siswa terhadap kebersihan lingkungan terutama pada lingkungan sekolah, karena sekolah merupakan tempat peserta didik memperoleh pendidikan dimana proses pendidikan berlangsung dengan tujuan untuk merubah tingkah laku ke arah yang lebih baik. Untuk menumbuhkan rasa kepedulian siswa terhadap kebersihan lingkungan di perlukan langkah-langkah yang konkrit untuk menjaga kebersihan lingkungan, seperti: mengadakan lomba kebersihan kelas atau mengadakan lomba kreatifitas yang bersifat ramah lingkungan dll. Dari survei kami sekolah MA AL MASYHUR Bugul Kidul Kota Pasuruan memiliki beberapa fasilitas yang sudah rusak dan tidak dilakukan perbaikan lagi, salah satu fasilitas yang rusak yaitu beberapa nama identitas sekolah yang sudah tidak lengkap, minimnya tempat sampah dan minimnya penghijauan di lingkungan sekolah. Bedasarkan hasil survei ini kami TIM KKN Universitas PGRI Wiranegara Pasuruan berinisiatif untuk membuat program kerja yang berguna dan dapat menumbuhkan rasa kepedulian siswa terhadap kebersihan lingkungan sekolah, program kerja ini akan membawa dampak positif yang berkelanjutan bagi kebersihan lingkungan sekolah dan bagi siswa maupun guru. Program kerja yang paling utama yakni membuat tempat sampah (kering dan basah), perbaikan nama sekolah, tanaman gantung, doodle art bertema go green dan sosialisasi mengenai pentingnya menaga lingkungan dan membuang sampah pada tempatnya.

Menurut Dalyono (2010:131) lingkungan sekolah merupakan salah satu faktor yang dapat mempengaruhi perkembangan dan pertumbuhan anak terutama bagi kecerdasannya. Lingkungan sekolah berperan penting dalam meningkatkan pola pikir anak, karerna kelengkapan sarana dan prasarana dalam belajar serta kondisi lingkungan sekolah yang sangat baik penting guna untuk mendukung terciptanya suasana lingkungan belajar mengajar yang menyenagkan. Sebagai suatu lembaga yang memberikan kesempatan belajar dan menyelenggarakan pengajaran harus memenuhi bermacam-macam persyaratan antara lain: Murid, guru, program pendidikan, asrama, sarana dan fasilitas. Segala sesuatu sudah disusun dan diatur menurut pola dan sisitematika tertentu sehingga memungkinkan kegiatan belajar dan mengajar berlangsung dengan efektif dan baik dan terarah pada pembentukan dan pengembangan siswa.

Kebersihan menurut Kamus Besar Bahasa Indonesia merupakan keadaan bebas dari kotoran termasuk diantaranya, debu, sampah dan bau. Manusia perlu menjaga kebersihan lingkungan dan kebersihan diri agar selalu sehat dan tidak menyebarkan kuman atau kotoran dan menularkan penyakit atau kuman bagi diri sendiri atau orang lain.

Jadi kebersihan lingkungan sekolah merupakan salah satu faktor yang menodorng siswa untul lebih bersemangat dan termotivasi dalma melaksanakan proses belajar mengajar, oleh karnanya lingkungan sekolah harus selalu di jaga. Dari pihak sekolah MA AL MASYHUR sudah berupaya untuk melakukan tindakan-tindakan yang berkaitan dengan kebersihan lingkungan sekolah seperti dengan adanya slogan tentang lingkungan dan kebersihan, tetapi masih kurang adanya tindakan-tindakan yang akan menumbuhkan rasa kepedulian siswa terhadap lingkungan sekolah. Oleh karena itu TIM KKN MA AL MASYHUR membuat sebuah program kerja yang berpengaruh untuk menumbuhkan rasa kepedulian siswa terhadap kebersihan lingkungan sekolah diantaranya yaitu membuat tempat sampah (kering dan basah), memperbaiki nama sekolah, 
membuat taman gantung, dan doodle art bertema go green. Dengan adanya tindaka-tindakan dan program kerja ini siswa akan sadar akan pentingnya menumbuhkan rasa kepedualiannya terhadap kebersihan sekolah dan dapat menciptakan lingkungan sekolah yang nyaman, bersih, bebas dari sampah yang berserakan dan dapat mendukung kegiatan proses belajar mengajar.

\section{METODE}

1. Pembuatan tempat sampah

Menurut Azwar (1990:53), mengatakan bahwa pengertian sampah adalah sebagian dari sesuatu yang tidak di pakai, tidak disenangi atau sesuatu yang harus di buang yang umumnya berasal dari kegiatan yang di lakukan manusia (termasuk kegiatan industri) tetapi bukan biologis karena kotoran manusia (human waste) tidak masuk kedalamnya.

Salah satu permasalahan yang paling utama yakni minimnya tempat sampah yang terdapat di MA AL MASYHUR, hal ini merupakan faktor penyebab utama yang menjadikan lingkungan sekolah menjadi kotor karena siswa cenderung membung sampah tidak pada tempatnya. Oleh karena itu TIM KKN Universitas PGRI Wiranegara Pasuruan membuat tempat sampah (kering dan basah), dalam pelaksanaannya kami memanfaatkan tong sampah bekas yang terbuat dari seng agar tempat sampah tersebut dapat di gunakan dalam jangka waktu panjang dan tidak mudah rusak, lalu kami memberi warna pada tong sampah tersebut dengan warna hijau dan kuning agar siswa dapat membuang sampah berdasarkan jenis sampah tersebut adapun sampah kering merupakan sampah yang banyak dihasilkan dari kertas, plastik, sedikit logam, dan sampah basah merupakan sampah yang berasal dari guguran daun pohon, sisa makanan atau daun pisang pembungkus makanan, dengan di bedakannya tempat sampah (kering dan basah) akan memudahkan siswa untuk membiasakan membuang sampah pada tempatnya sesuai dengan jenis sampahnya. Setelah itu kami membuat kerangka tong sampah agar tong sampah tidak di letakkan langsung di atas tanah dan tidak mudah karatan, kerangka tersebut terbuat dari kayu bekas yang di cat menggunakan warna hitam agar tidak mudah terlihat kotor. Ketika tempat sampah sudah tersedia tentunya siswa bisa termotivasi untuk membuang sampah pada tenpatnya serta berdasarkan jenisa sampahnya dan dapat menciptakan suasana lingkungan sekolah yang bersih, sehat, nyaman.

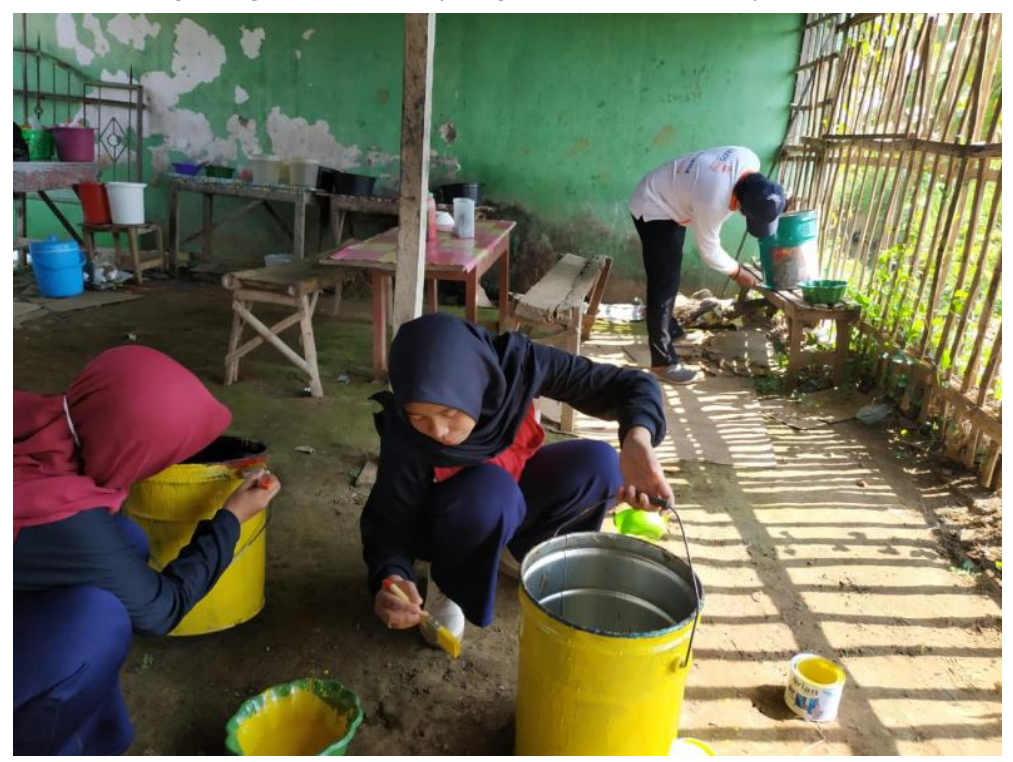

Gambar 1. Proses Pembuatan Tempat Sampah 


\section{Peremajaan Papan Nama Sekolah}

Nama sekolah merupakan identitas utama yang menunjukkan adanya lembaga pendidikan, dengan adanya identitas atau nama sekolah akan memudahkan bagi masyarakat atau siswa ketika ingin mengenyam pendidikan di sekolah tersebut, sedangkan kondisi papan nama sekolah di MA AL MASYUR terdapat banyak huruf yang sudah rusak dan terlepas selain itu alamat yang terdapat pada papan nama tersebut salah, hal ini menyebabkan identitas nama sekolah menjadi tidak terlihat sehingga masyarakat dari luar pun agak susah dalam mencari sekolah tersebut, ditambah lagi tepat di bawah papan nama sekolah terdapat taman kecil yang sudah rusak dan tidak di tanami oleh tumbuhan.

Oleh karna itu Kami TIM KKN MA AL MASYHUR Bugul Kidul Kota Pasuruan melakukan perbaikan nama tersebut, dalam pelaksanaanya langkah awal yang kami lakukan yakni membeli peralatan papan nama tersebut, adapun bahan yang kami gunakan untuk nama sekolah yaitu menggunakan alas sandal yang berwarna hitam, setelah itu kami mencetak huruf sesuai dengan identitas nama sekolah menggunakan kertas yang di print, lalu kami memotong huruf tersebut menggunakan gunting dan cutter, lalau langkah selanjutnya yaitu mengelupas nama yang sudah ada sebelumnya menggunakan cutter dan juga bensin untuk mempermudah melepaskannya, lalu kami membersihkan alas atau lantai dari tempat nama tersebut menggunakan kain pel, setelah semuanya bersih kami menempelkan huruf tersebut menggunakan lem rajawali agar dapat bertahan dengan lama. Untuk mengisi taman yang sudah kosong kami mengisi nya dengan tanaman kecil adapun tanaman tersebut yaitu tanaman bulu ayam, kami menata tanaman tersebut dengan lurus agar terlihat tumbuh dengan rapi, kami juga mengisi taman tersebut dengan bebatuan kecil yang sudah di beri warna hijau agar terlihat lebih hidup.

Dengan dilaksanakannya perbaikan papan nama dan taman menjadikan suasana lingkungan yang asri, indah dan nyaman, identitas nama sekolahpun menjadi mudah dikenali oleh siapun baik itu guru, siswa atau masyarakat di sekitar dan dengan adanya taman kecil dapat memperindah estetika nama sekolah tersebut, apalagi bagunan fisik atau sekolah MA AL MASYHUR Bugul Kidul Kota Pasuruan terletak di seberang jalan yang otomatis banyak orang yang lalu lalang di jalan tersebut.

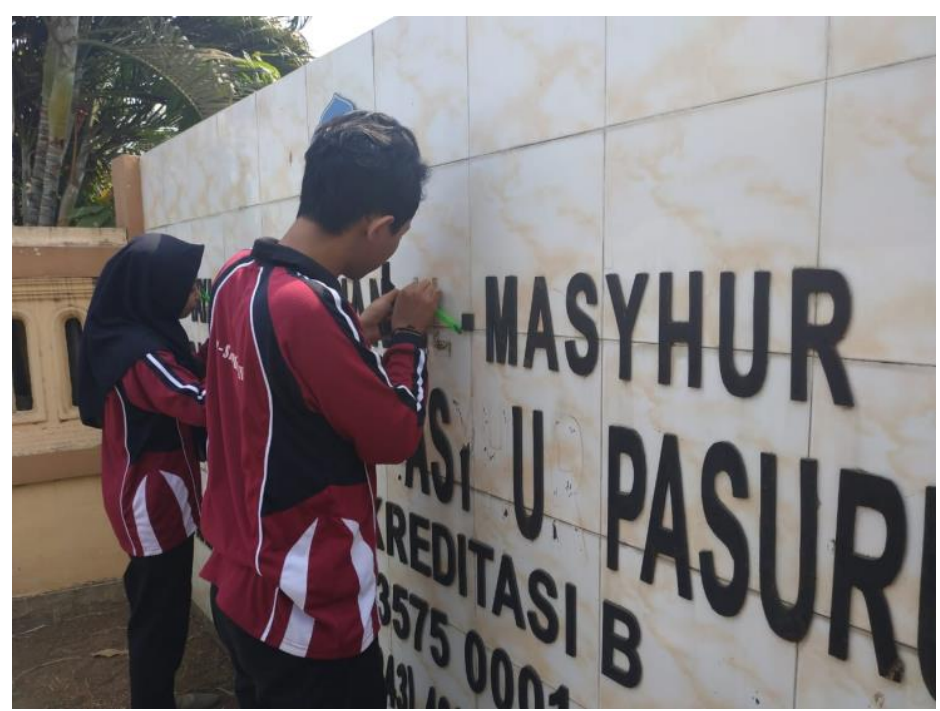

Gambar 2 Proses Peremajaan Papan Nama MA Al Masyhur 


\section{Taman Gantung}

Laurie (1986) mengatakan bahwa asal mula pengertian kata taman (garden) dapat ditelusuri pada bahasa ibrani gan, yang berarti melindungi atau mempertahankan, menyatakan secara tidak langsung hal pemagaran atau lahan berpagar, dan eden atau oden, yang memiliki arti kesenangan atau kegembiraan. Jadi dalam bahasa Inggris perkataan "garden" memiliki gabungan yang berasal dari dua kata-kata tersebut, yang berarti sebidang lahan perpagar yang dapat digunakan untuk kesenangan dan kegembiraan. Awal mula dilaksanakannya salah satu program kerja ini yaitu TIM KKN MA AL MASYHUR Bugul Kidul Kota Pasuruan kami menemukan seonggok papan yang terbengkalai di sudut sekolah yang tidak dipakai dan tampak usang, lalu kami putuskan menggunakan papan tersebut sebagai rak gantung tempat bunga, karena taman gantung tidak memerlukan banyak lahan atau tempat, untuk merawat taman ini pun tidaklah sulit. Dalam pelaksanaannya hal pertama yang kami lakukan yaitu membersihkan papan tersebut lalu memberikan warna agar kayu tersebut tidak terlihat kotor, setelah itu papan itu kita gantung di dinding lalu kami isi tanaman yang di tanam di dalam pot lalu meletakkannya di dalam rak tersebut. Adapun bunga yang kami gunakan di dalam rak gantung tersebut yaitu daun sirih gading. Alasan pemilihan bunga sirih gading ini adalah selain indah, juga mudah dalam perawatannya.

Mengenai perawatan taman gantung ini, setiap pagi kami menyirami taman tersebut dengan tujuan agar siswa maupun warga sekolah dapat mencontoh sikap atau tindakan positif kami terhadap lingkungan sekolah dan dapat menumbuhkan rasa kepeduliannya kepada lingkungan sekolah. Dengan adanya taman gantung ini sekolah juga dapat memberikan peluang bagi para guru atau murid dalam meningkatkan kreatifitasnya dengan cara mengadakan suatu pembelajaran berkelompok menciptakan tanaman sayuran organik yang menggunakan media pot untuk menanam dan tidak memerlukan tempat atau lahan yang luas. Ketika siswa maupun guru sadar akan pentingnya menjaga kebersihan lingkungan sekolah maka akan tercipta lingkungan sekolah yang produktif dan menyenangkan.

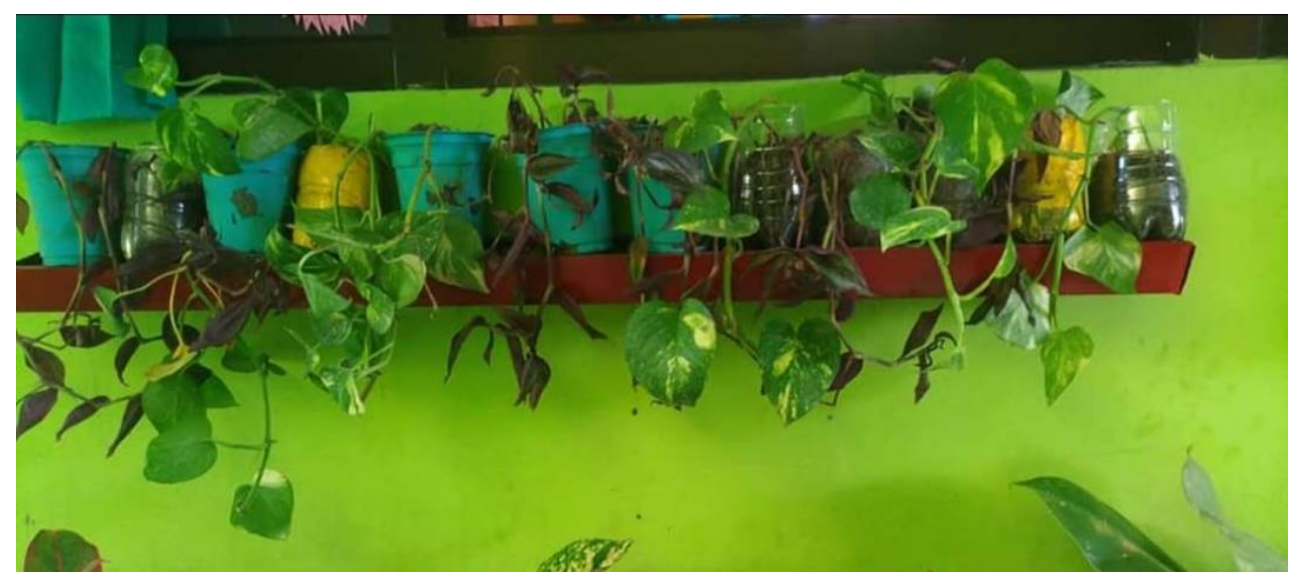

Gambar 3 Taman Gantung

\section{Doodle Art Bertema Go Green}

Doodle Art merupakan media ekspresi yang kami gunakan dalam upaya melatih siswa untuk menumbuhkan rasa kepeduliannya terhadap lingkungan sekolah, dengan menyediakan media bagi mereka untuk mengekspresikan kegemarannya dalam mengkreasikan berbagai gambar positif yang 
dapat membangun karakter siswa. Dalam hal ini terdapat tembok polos tepat di depan taman kecil yang tidak terawat, dengan adanya tembok kosong ini kami memutuskan untuk membuat doodle art dan mengangkat tema go green, alasan kami menggunakan tema go green yaitu untuk menyadarkan kita agar senantiasa menjaga dan melestarikan alam ini bukan malah merusaknya. Dalam pelaksanaanya, langkah awal yang kami lakukan yaitu membersihkan tembok tersebut lalu mengecat tembok tersebut menggunakan cat tembok berwarna putih sebagai warna dasar dan mempermudah kami dalam melukis gambar, setelah itu kami perlahan lahan menggambar tembok tersebut dengan cat berwarna hitam dan menggunakan kuas lukis yang berukuran paling kecil, adapun bahan cat yang kami gunakan yaitu cat akrilik agar gambar terlihat lebih menarik, langkah selanjutnya yaitu memberi warna pada tembok yang sebelumnya sudah di gambar, dan kami mengguanakan berbagai macam warna diantaranya yaitu: putih, merah, hijau, kuning, ungu, biru, orange, merah bata, pink, hitam dll, dan kami memberikan warna hijau pada gambar yang bertuliskan go green karna warna tersebut mengidentitaskan akan tanaman yang berwarna hijau. Selain itu kami juga menata ulang taman yang terdapat tepat di tulisan tersebut agar tulisan terlhat lebih enak di pandang.

Dengan adanya doodle art bertema go green dan didukung dengan taman di depannya secara tidak langsung dapat memotivasi dan menumbuhkan rasa kepedulian sisiwa terhadap kebersihan lingkungan dan juga mengajak mereka untuk peduli akan lingkungan dan penghijauan, di tambah lagi doodle art ini terletak di dekat gerbang sekolah yang dapat menambah keindahan estetika sekolah. Dengan terlaksananya program kerja ini penataan sekolah menjadi hijau dan segar sehingga dapat menciptakan suasana yang asri, bersih, sejuk, sehat dan mendukung proses belajar mengajar. Lingkungan sekolah yang kondusif akan mendorong terwujudnya pola hidup siswa yang bermutu, dan juga penghijauan di wilayah sekolah dapat mengurangi peristiwa global warming, menyejukkan udara di sekitar sekolah dan dapat memperindah pemandangan.

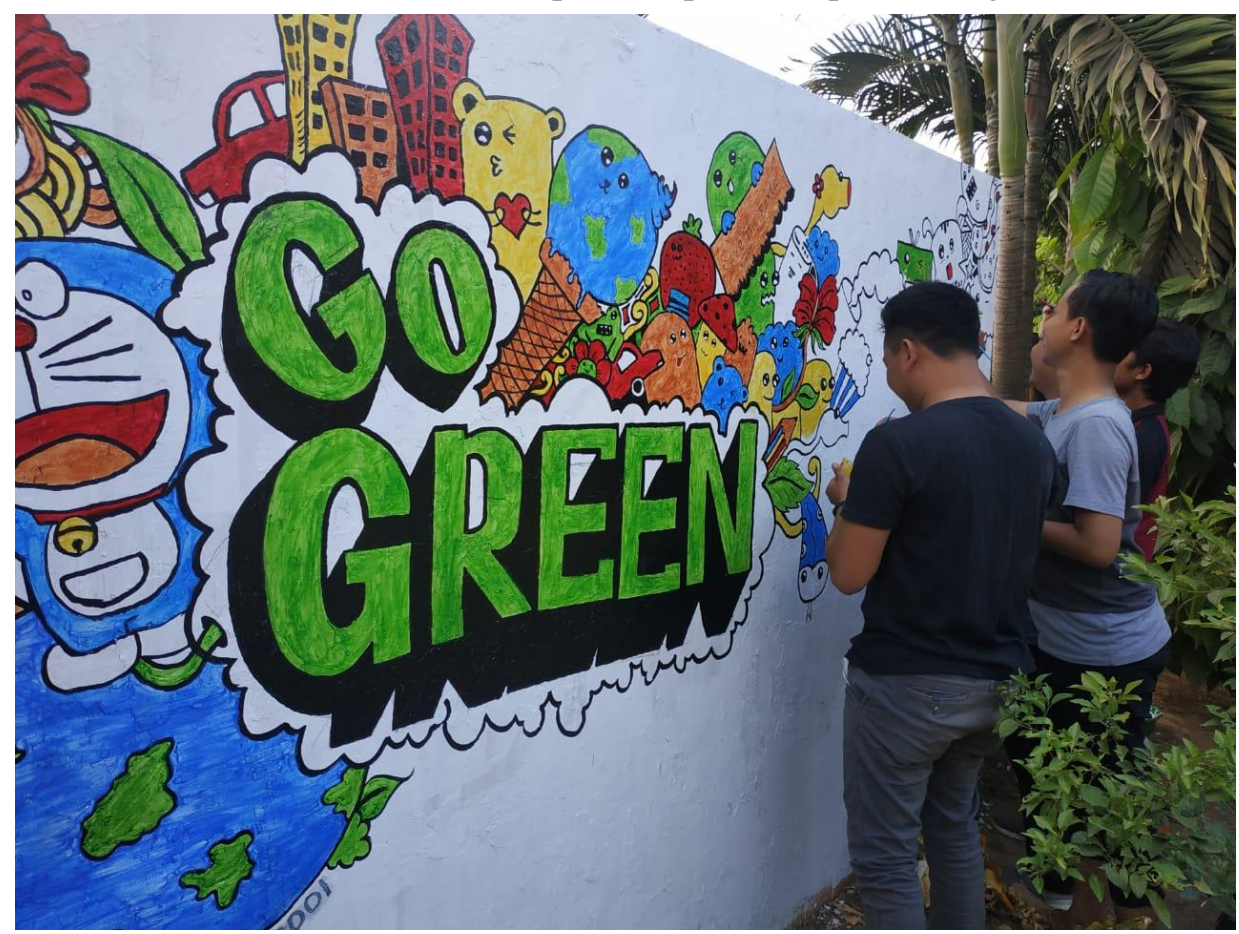

Gambar 4 Proses pengecatan doodle art bertema Go Green 
5. Sosialisasi mengenai sampah dan kebersihan sekolah

Menurut Ritcher JR (1987:139), mengatakan bahwa sosialisasi merupakan proses seseorang memperoleh pengetahuan, keterampilan dan sikap yang diperlakukannya agar dapat berfungsi sebagai orang dewasa sekaligus sebagai pemeran aktif dalam suatu kedudukan atau peranan tertentu di masyarakat. Kegiatan sosialisasi yang kami lakukan yaitu bertujuan untuk mengedukasi siswa kelas X dan XI MA AL MASYHUR Bugul Kidul Kota Pasuruan mengenai pentingnya membuang sampah pada tempatnya sesuai dengan jenis sampah yang mereka miliki dan menjelaskan kepada mereka perbedaan antara tempat sampah yang berwarna hijau dan kuning, kami juga memberikan sedikit contoh tentang bagaimana cara membuang sampah dengan benar, seperti membuang sampah kertas yang tidak di pakai ke dalam tempat sampah yang berwarna hijau. Di dalam sosialisasi ini kami juga menginformasikan kepada siswa berbagai program kerja yang telah kami laksanakan agar siswa mengerti maksud dan tujuan utama kami menciptakan program kerja tersebut, kami menghimbau mereka agar senantiasa menjaga serta meneruskan dan tidak merusak apa yang telah kami ciptakan di dalam sekolah tersebut agar bermanfaat bagi mereka semua dan program kerja yang telah kami ciptakan tidak musnah begitu saja ketika kami telah meninggalkan sekolah tersebut.

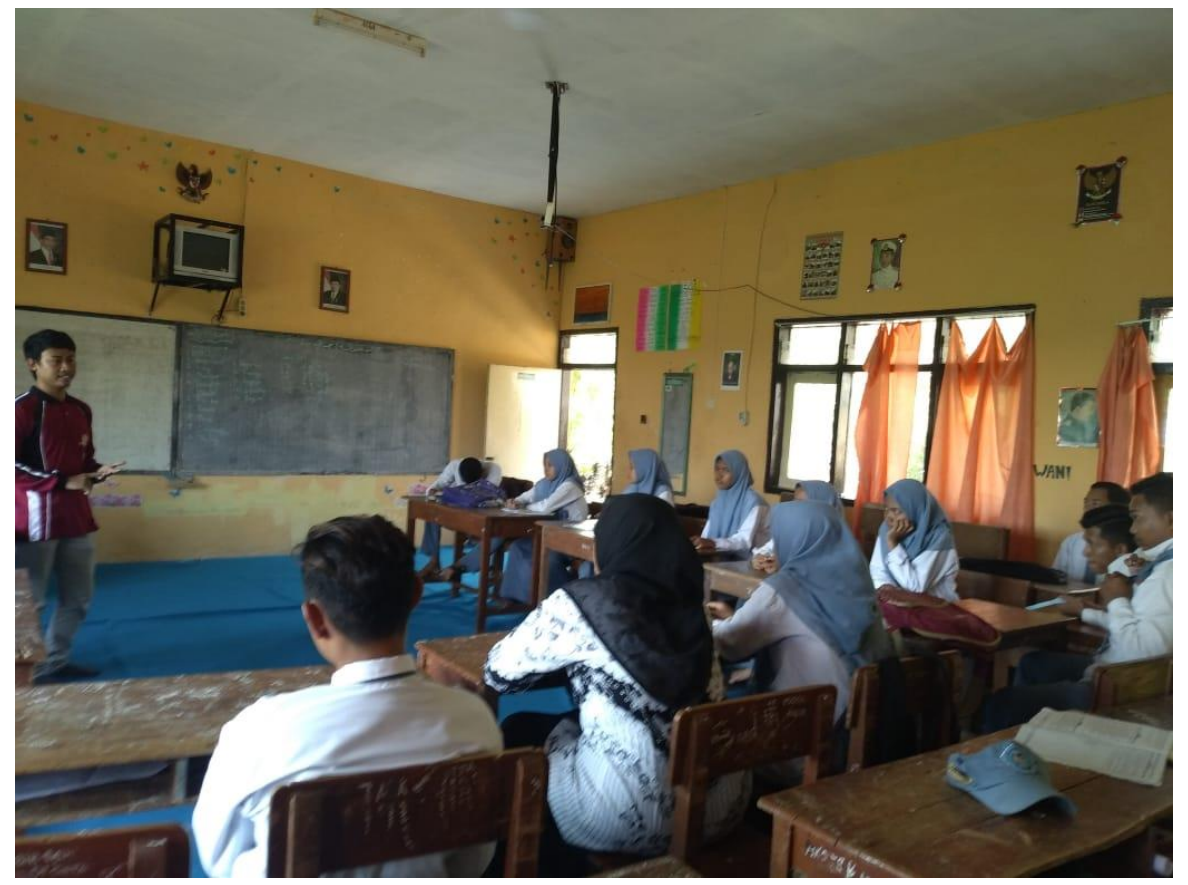

Gambar 5 Sosialisasi tentang sampah dan pentingnya kebersihan lingkungan

\section{HASIL DAN PEMBAHASAN}

Selama KKN berlangsung kami menemukan berbagai permasalahan yang terdapat pada sekolah MA AL MASYHUR Bugul Kidul Kota Pasuruan, diantaranya yaitu sebagai berikut:

1. Kurangnya penghijauan di lingkungan sekolah

2. Minimnya kesadaran akan membuang sampah pada tempatnya

3. Minimnya fasilitas tempat sampah di sekolah

4. Kurangnya minat siswa untuk mengikuti kegiatan sosialisasi 


\section{Tidak adanya staff keamanan di sekolah}

Merubah lingkungan sekolah menjadi bersih memang bukanlah perkara yang sulit jika guru dan siswa saling bekerja sama, kompak dan mempertahankan lingkungan yang bersih, jika siswa kurang memiliki rasa kepedulian dan kecintaan terhadap lingkungan dan penghijauan maka suasana sekolah akan terlihat kotor, kumuh, gersang dan tidak terawat. Bahkan kemungkinan besar keadaan ini akan menganggu proses belajar mengajar, mengganggu motivasi dan minat mereka terhadap pembelajaran mereka di sekolah, begitu pula sebaliknya dengan terciptanya lingkungan sekolah yang bersih, nyaman dan terdapat banyak penghijauan akan menimbulkan banyak hal positif dan memberikan dampak positif lain yang berkelanjutan atau berkepanjangan yang dapat bermanfaat bagi guru dan siswa. Berbagai program kerja lingkungan yang kita lakukan merupakan hal yang sangat di butuhkan dan berpengaruh untuk menunjang kebersihan dan penghijauan di lingkungan sekolah, dan program kerja yang kami lakukan bisa memberikan inspirasi dan inovasi baru bagi siswa MA AL MASYHUR Bugul Kidul Kota Pasuruan.

\section{SIMPULAN}

Dengan telaksananya semua program kerja lingkungan TIM KKN Universitas PGRI Wiranegara Pasuruan yang mendapat tanggapan, respon positif dan sambutan baik dari MA AL MASYHUR Bugul Kidul Kota Pasuruan khususnya siswa dan warga sekolah. Kami berharap dengan adanya tindakan-tindakan dan inovasi baru yang kami berikan, siswa menjadi termotivasi dan memiliki tanggung jawab untuk menumbuhkan rasa kepeduliannya terhadap lingkungan sekolahnya, di mana sekolah tersebut merupakan tempat bagi mereka untuk belajar dan menempuh pendidikan. Program kerja tim lingkungan ini dapat menumbuhkan dan memotivasi siswa untuk menjaga kebersihan lingkungan sekolah demi terwujudnya lingkungan sekolah yang bersih, rindang dan nyaman.

\section{SARAN}

Kami berharap dengan adanya programa kerja lingkunang ini dapat menumbuhkan hal yang baru yang telah kami ciptakan dapat bermanfaat bagi guru maupun siswa dan siswa dapat menjaga dan mengembangkannya agar program tersebut tidak musnah ketika kami sudah meninggalkan sekolah.

\section{DAFTAR PUSTAKA}

Azwar, Azrul. (1990). Pengantar Ilmu Kesehatan Lingkungan. Jakarta, Yayasan Mutiara. Dalyono, M. (2010:131). Psikologi Pendidikan. Jakarta : Rineka cipta.Djiwandono. Hamalik, Oemar. (2009:6). Proses Belajar Mengajar. Jakarta, Bumi Aksara. Laurie, M. (1986). Pengantar Kepada Arsitektur Pertamanan. Bandung, Intermatra. Ritcher, JR. (1987:139). An Econometrics Analysis of Income Tax Evasion and its. Dectection. RAND Journal of Economics, Vol.22 No.1, p.14. 